\title{
Experimental Organism Malignant Mesovarial Leiomyoma
}

National Cancer Institute

\section{Source}

National Cancer Institute. Experimental Organism Malignant Mesovarial Leiomyoma. NCI

Thesaurus. Code C124610.

A smooth muscle neoplasm with malignant charcateristics that arises from the mesovarium. 